\title{
A REVISION OF DISTRIBUTION AND THE ECOLOGICAL DESCRIPTION OF Orobanche picridis (Orobanchaceae) AT THE NE LIMIT OF ITS GEOGRAPHICAL RANGE FROM POLAND AND UKRAINE
}

\author{
Renata Piwowarczyk \\ Department of Botany, Institute of Biology, Jan Kochanowski University, \\ Świętokrzyska 15, 25-406 Kielce, Poland \\ e-mail: renka76@wp.pl
}

Received: 27.11.2011

\begin{abstract}
The paper presents the current distribution of Orobanche picridis in Poland and Ukraine, within the Polish borders in the interwar period, based on a critical revision of herbarium and literature data as well as the results of my field studies. The largest number of its localities is in S and SE Poland in the Wyżyna Śląsko-Krakowska, Wyżyna Małopolska, Wyżyna Lubelska uplands, Middle Roztocze, Small Polesie, the Pogórze Przemyskie foreland and in the former Tarnopol province (W Ukraine). These are the north-easternmost sites known for the species and extend its limit range. A map of its distribution in Poland and Ukraine is included. The taxonomy, biology, and ecology of $O$. picridis are also discussed.
\end{abstract}

Key words: Orobanche picridis, Orobanchaceae, distribution, phytocoenoses, Poland, Ukraine

\section{INTRODUCTION}

Orobanche picridis F. W. Schultz is a root holoparasite, belonging to the parasitic family Orobanchaceae. It is a Submediterranean-Subatlantic species. Its continuous range mostly covers south-western Europe, stretching from Portugal, Spain, across the Mediterranean region, France, southern Germany and Austria, to the Balkans. Individual localities occur in southern England and from northern France across the Czech Republic, Slovakia, southern Poland and Romania, Ukraine, Russia. It has been sporadically reported from Asia Minor, the Transcaucasian region and northern Africa (B e ck, 1930; Uhlich et al. 1995; Tzvelev, 2006; Pusch and Günther, 2009). Localities in Poland and Ukraine are the north-eastern limit of its range. The north-easternmost isolated locality was reported from Bryansk village on the Desna in western Russia near the Ukraine/Belarus border ( $\mathrm{Tzve}$ le v, 2006). The range of the species, especially in the Mediterranean region, is likely to be inaccurate as the taxon was often included in O. loricata agg. there (e.g. D o m in a and A rrig on i, 2007). The approach was similar in, e.g., Bulgaria (Deli pavlov, 1995; Stoyanov, 2009). The species is threatened with extinction in Poland $(\mathrm{Zarz} \mathrm{ycki}$, 2001; Piwowarczyk, 2012b) and in the neighbouring countries, i.e. Germany, the Czech Republic, Slovakia (Korne ck et al. 1996; F e rák ová et al. 2001; Pr o c házk a, 2001).

The aim of my study was to identify the distribution of Orobanche picridis in Poland and western Ukraine (Polish territories in the interwar period) based on my investigations and verified herbarium and literature data. The preferred habitats, communities, hosts and taxonomic problems are also discussed below.

\section{TAXONOMIC PROBLEMS}

Orobanche picridis F. W. Schultz Bot. Literatur-Blätter, Regensburg, 5: 504, 1830. Syn.: O. picris hieracioides Schultz, 1830; O. carotae Desmoulins, 1835; O. loricata var. picridis (F.W. Schultz) Beck in Halácsy et Braun Nachtr. Fl. Nieder-Österr. 135, 1882; O. artemisia-campestris subsp. picridis (F.W. Schultz) O. Bolňs et al. Fl. Manual Paisos Catalans 1214, 1990.

Orobanche picridis belongs to the subsection Minores (Beck) Teryokhin. The species of this group require a taxonomic revision. $O$. picridis is not a highly variable taxon in comparison with other species of the genus. The height of the shoot and the number 
of flowers in individuals often vary within one population. Two varieties: var. typica (plant glandular hairy, inflorescence having many flowers, flowers 15-20 mm long, calyx segments mostly yellowish-white) and var. carotae (plant less glandular hairy, corolla later almost glabrous, violet-veined also in dry, calyx segments dark-coloured), and three forms: f. typica, f. albo-bracteata, f. parviflora (B e c k, 1930) have been described within the species. The typical variety var. typica dominates in Central Europe and is generally more common. The variety var. carotae has been observed in the Mediterranean region (Beck, 1930).

Orobanche picridis is morphologically very similar to $O$. minor and to $O$. artemisiae-campestris. Calyx segments are usually divided up to $1 / 2$ into two similarly sized parts in $O$. picridis, while they are divided up to the base in $O$. artemisiae-campestris. Other characters are similar. The species is also similar to the $O$. minor agg. species complex, especially when dry. Determining the herbarium material is often complicated and information on the host is of considerable use. The hosts of the species in Central Europe are as follows: O. picridis - Picris hieracioides, O. artemisiae-campestris - Artemisia campestris, O. minor Trifolium pratense, $T$. repens.

\section{BIOLOGY AND PHYTOCOENOSES}

Flowering period. It flowers from mid-June to the end of July (August), from April in southern Europe. It may flower later (X-XI) in unfavourable climatic conditions but such plants are often sterile (Z á z v o r $\mathrm{k} \mathrm{a}, 2000)$.

Seed productivity. Orobanche picridis produces between 450 and 3250 seeds, 1780 seeds per fruit on average. From 8900 to 150 000, over 55000 seeds on average, is recorded per shoot ( $\mathrm{Piw} \mathrm{ow}$ a r c z y k, 2012c).

Hosts. Numerous host species are reported in the literature: Picris sp., P. hieracioides, P. laciniata, $P$. vulgaris, Crepis diffusa, C. vesicaria, Tragopogon campestris, Cirsium sp., Inula graveolens, I. revoluta, Hypochoeris infesta, Centaurea sp., Daucus carota, Orlaya grandiflora, Salsola vermiculata, Ornithopus compressus (B e c k, 1930). Plants occurring closest to the parasite that may not have been its hosts were often noted, which may explain the number of erroneous host species belonging to several genera. Fully accurate data can only be collected after the plant has been dug up. Picris hieracioides is usually listed as its host in the majority of studies. Daucus carota reported considerably less frequently as its host is unclear and doubtful. D. carota and P. hieracioides often occur near each other in communities preferred by O. picridis (Dauco-Picridetum hieracioidis), which may cause mistakes. Morphologically similar $O$. minor subsp. maritima (O. maritima) also parasitizes Daucus carota subsp. gummifer (R u m s e y, 2007).

Phytocoenoses and habitat conditions. Orobanche picridis has been noted in calcareous and gypsum wastelands in Dauco-Picridetum hieracioidis, Arrhenatherion elatioris, Sisymbrion, Dauco-carotae-Melilotion albi communities (O b e r d o r f e r, 1983; Uhlich et al. 1995; Heseler, 2006; R othmaler et al. 2002; Pu sch and Günther, 2009). In the Czech Republic and Slovakia, it prefers young and slightly older fallows, fluvial terraces and margins of vineyards and gardens on acidic or neutral soils, limestone, marl, conglomerates, loess or basalt. It also occurs on permanently eroded open areas or on steep slopes with fresh landslides in the initial phase of Dauco-Melilotion and Dauco-Picridetum communities (Holub and Zázvorka, 1999; Zá z vorka, 1997; Zá z v or ka, 2000). In Germany plant communities with broomrape also include calcareous wastelands, orchards, fallows, semiruderal grasslands, roadsides, meadows in the Dauco-Picridetum hieracioidis community (H e s e l e r, 2006). In Eastern Europe it has been reported from unweeded meadows, forest glades, forest margins, steppe slopes, roadsides and field margins (K o t o v , 1999; T z v e le v, 2006).

\section{MATERIALS AND METHODS}

I reviewed all the herbarium materials of Orobanche picridis available in Poland. The materials of O. picridis examined by me were deposited in the herbaria LOD, KTC, KRA, KRAM, OPOL. Herbarium acronyms are given after Mirek et al. (1997). The nomenclature of vascular plants follows $\mathrm{Mirek}$ et al. (2002). The nomenclature of syntaxa is based on M a t u s zki e w i c z (2006). Field studies were conducted between 1999-2011 and intensified from 2005 to 2011. The localities are listed in ATPOL cartogram units, 10 x $10 \mathrm{~km} \mathrm{Zając} \mathrm{(1978).} \mathrm{Units} \mathrm{are} \mathrm{listed}$ in alphabetical order. Only localities recorded in my observations and identified or confirmed, as well as verified herbarium data are listed below. Published data not confirmed by me in the field or undocumented by the herbarium material are not included due to frequent determination errors. The localities are described as follows: ATPOL grid unit, location, habitat description, abundance (in brackets). The following information is also given for most localities: geographic co-ordinates and altitude (above sea level), revised exsiccata: the collector and collection date, the herbarium acronym and exsiccata number. Names of the sites in Ukraine are given according to the 
herbarium label and the current English name is provided in brackets.

\section{RESULTS}

\section{Distribution at NE limit}

In Poland Orobanche picridis has been reported from 34 localities. Nearly all of them have been discovered in the last ten years. In Poland it mostly occurs in the south, in the Wyżyna Śląsko-Krakowska and Wyżyna Małopolska uplands, and in the south-east, in the Wyżyna Lubelska upland, Middle Roztocze, Small Polesie, and the Pogórze Przemyskie foreland (K o tu la , 1881; S z e lą g, 1996; B róż et al. 2001; Kucharczyk, 2001; Piwowarczyk，2010, 2012a, b, c; Piwowarczyk and Przemyski, 2009, 2010; Piwowarczyk et al. 2011; Zaj ąc and $\mathrm{Z} \mathrm{a} \mathrm{j} \mathrm{ą} \mathrm{c} \mathrm{,2001)} \mathrm{(Figs.} \mathrm{1,} \mathrm{2).} \mathrm{A} \mathrm{few} \mathrm{general} \mathrm{reports}$ on the occurrence in Ukraine are available: the area of Lviv (S z a f e r et al. 1924; T z vele v, 1981; K o tov, 1999) and Pasieczna (S z a fer et al. 1924), Roztocze, Miodobory, western and southern Podolia (M ą d a ls k i , 1967). The north-easternmost isolated locality has been reported from Bryansk village on the Desna river in western Russia near the Ukraine/Belarus border (T z v e l e v , 2006) (Fig. 2).

\section{Poland}

List of localities: CF: 27 - Leśnica, cfr., leg. Dziatzko, 28.06.1897 (OPOL, P/3465); DE: 69 - Murawy Dobromierskie reserve near Dobromierz, wasteland on the margin of a pine forest and xerothermic grassland (>1000), 51 ${ }^{\circ} 00^{\prime} 29,7^{\prime \prime} \mathrm{N}, 1^{\circ} 54^{\prime} 52,1^{\prime \prime} \mathrm{E}, 303 \mathrm{~m}$, leg. P. Niedźwiedzki, 09.07.2006 (LOD, 154348), leg. R. Piwowarczyk, 04.06.2008 (KTC), (P i w o w a r c zyk, 2012 a,b,c); 85 - Małusy Małe, xerothermic grassland in the SSW part of Wzgórze Bożykowskie hill (<200), 5047’41,6”N, 19¹8'28,5”'E, 298 m, leg. J. Blaszczyk, 28.07.1948 (KRA, 900124), leg. prof. Pogan, 02.08.1948 (KRA, 0299230); Błaszczyk 1949, leg. J. Kołodziejek, 07.07.1982 (LOD, 084146), leg. R. Piwowarczyk, 04.06.2008 (KTC), (P i w o w a r czyk, 2012 a,b,c); DF: 26 - Zawiercie-Bzów SE, hill $445 \mathrm{~m}$, NW slopes, wastelands/initial xerothermic grassland (>250), 50 28'08'N, 19³1'32'"E, 435 m, leg. Ł. Krajewski, 15.07.2010 (KTC); 34 - Będzin-Warpie, lawn on the roadside (3), $50^{\circ} 18^{\prime} 59^{\prime \prime} \mathrm{N}$, 1909'19”E, 295 m, (Ł. Krajewski, 28.07.2009, unpbl); 35 - Dąbrowa Górnicza-Strzemieszyce Małe E, hill 335, E slopes, wastelands $(200,>450,1)$, $50^{\circ} 19^{\prime} 16^{\prime \prime} \mathrm{N}, 19^{\circ} 19^{\prime} 48^{\prime \prime} \mathrm{E}, 320-335 \mathrm{~m}$, leg. Ł. Krajewski, 07.10.2009, 16.07.2010 (KTC), (Ł. Krajewski, 2009-2011, unpbl.); Sławków NW, Góra Wielka Mt (>150), 50¹9'12,8'N, 19²1'07,2'E, 348 m, leg. R. Piwowarczyk, 12.07.2007 (KTC); Sławków
NW, Góra Tomanówka Mt NE, wasteland/initial xerothermic grassland (20), 50'19'27' $\mathrm{N}, 19^{\circ} 21^{\prime} 20^{\prime \prime} \mathrm{E}$, 335-340 m, leg. Ł. Krajewski, 09.08.2009 (KTC); Sławków-Kozioł NW, wastelands with Libanotis and Solidago (250), 50¹8'35'N, 19²1'41'ㅌ, 325 m, leg. Ł. Krajewski, 07.09.2009 (KTC); Sławków N, E part of hill $345 \mathrm{~m}, \mathrm{~N}$ slopes of summit (15), $50^{\circ} 18^{\prime} 45^{\prime \prime} \mathrm{N}$, 19²2'50”'E, 325 m, leg. Ł. Krajewski, 07.09.2009 (KTC); Dąbrowa Górnicza-Zakawie SW, wastelands $(20,6), 50^{\circ} 18^{\prime} 37^{\prime \prime} N, 1^{\circ} 19^{\prime} 59^{\prime \prime} \mathrm{E}$, leg. Ł. Krajewski 03.09.2009 (KTC), (Krajewski 2009-2010, unpbl.); 58 - Wąwóz Bolechowicki gorge (150) (Szeląg, 1996); EF: 13 - Góry Pińczowskie Mts: between Skowronno and Pińczów, ecotone zone of xerothermic grasslands and fallows, wastelands on slopes, two abundant populations ( $>150,<200), 50^{\circ} 32^{\prime} 08,3^{\prime \prime} \mathrm{N}$, 20³0'55,6”'E, 247 m, leg. R. Piwowarczyk, A. Przemyski, 04.07.2006 (KTC), (P i w o w a r c z y k, 2012 a,b,c); 14 - between Pińczów and Pasturka, xerothermic grassland, ecotone zones of a grassland and an arable field, S and SSW-facing; scattered locality $(>50)$, $50^{\circ} 30^{\prime} 35,45^{\prime \prime} \mathrm{N}, 20^{\circ} 33^{\prime} 35^{\prime \prime} \mathrm{E}, 219 \mathrm{~m}, 50^{\circ} 30^{\prime} 26,45^{\prime}{ }^{\prime} \mathrm{N}$,

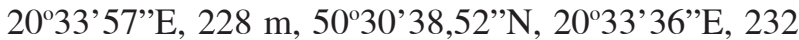
m, leg. R. Piwowarczyk, 25.06.2007 (KTC); Nowy Folwark, a fallow in the NW part of a forest complex (>50), 50'30'04”N, 2041'20,8'E, $250 \mathrm{~m}$, vid. P. Cieślak, 2009, (Piw ow a r c zyk, 2012 a,b,c); 22 - Słaboszów (B inkiewicz B. unpbl 2010); 23 - Wola Chroberska, E part, xerothermic grassland on a steep slope, E side of a dirt road (>10), 50'23'57,3”N, 2031'16"E, $230 \mathrm{~m}$, leg. R. Piwowarczyk, A. Prze m y s ki, 19.07.2006(KTC), (P i w o w a r czyk, 2012 a,b,c), (Piwow arczyk, 2012 a,b,c); 25 - xerothermic grassland $\mathrm{E}$ of the dirt road to Żerniki Górne (>15), 50²7'29”'N, 2047'28'E, 260 m, leg. M. Nobis, 2009 (KRA), (N o b is and N o b i s 2010); Ostra Góra ecological site, S of Pęczelice, S-facing wastelands and field margins (>100), 50'26'34”N, 20 47'05'E, 239 m, vid. A. Przemyski, 2010, leg. R. Piwowarczyk, 13.07.2010 (KTC), (P i w o w a r c z y k, 2012a,b,c); Przęślin reserve near Chotel Czerwony, S- and SW-facing xerothermic grassland, partly grazed (>30), 50²2'40,6”N, 2042'59'E, $197 \mathrm{~m}$, leg. R. Piwowarczyk, A. Przemyski, 05.07.2006 (KTC), (Piwowarczyk, 2012 a,b,c); 30 - Szczepanowice, S-facing xerothermic grassland on Kaczorowe Doły hills (2 shoots), 50² 18 '25,5”N, 20 03'28,4”E, 260 m, vid. R. Piwowarczyk, 2009, (P i w o w a r czyk, 2012 a,b,c); 31 - vicinity of Miechów, NW part, warm hill, post-agricultural meadow, leg. M. Szewczyk, 09.07.2002 (KRAM, 527156); the forest complex in the $\mathrm{N}$ of the Opalonki reserve, near the forest path (1 shoot), 50'21'02,49'N $20^{\circ} 10^{\prime} 30,36^{\prime \prime} \mathrm{E}$, vid. K. Ciesielski, 07.2011; 50 - Wiktorowice near 
Raciborowice, xerothermic grassland (>10), leg. K. Towpasz, 17.06.1995 (KRA); FE: 51 - Pętkowice, xerothermic grassland and wasteland at the foot of the left slope of the Kamienna river valley $(>100)$ (B róż et al. 2001; Piwowarczy k, 2010 b, 2012

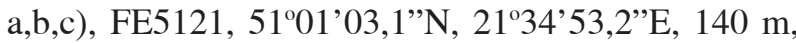
leg. R. Piwowarczyk, 04.07.2004, 21.06.2005 (KTC); $52-\mathrm{S}$ and SE of Dorotka village, xerothermic grassland (>20) (Piw ow arczyk, 2010 b, 2012 a,b,c, Piwowarczyk et al. 2011), 50 $59^{\prime} 56,33^{\prime \prime}$, 21 47 '11,46”'E, 166 m, vid. R. Piwowarczyk, 20012006, leg. R. Piwowarczyk, 05.2001 (KRA, 0267164); 01.06.2002, (KTC); Kucharczyk (2001) also reports the species from Dorotka; 62 - Wesołówka near Tarłów, fallows, baulks, field margins and initial xerothermic grassland, on chalky rendzinas, scattered locality $(<600)$ (B ró ż et al. 2001; Piwowar czyk, 2006, 2010, 2012 a,b,c, Piwowarczyk et

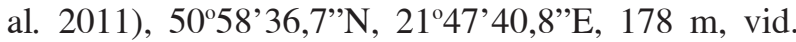
R. Piwowarczyk, 1999-2010, leg. R. Piwowarczyk, 07.1999, 13.07.2004, 01.08.2010 (KTC); 68 - Nowy Dwór, fallow fields, roadsides, in fringe communities and fragmentary patches of xerothermic grasslands on the slopes of the „Biała Góra” hill, (>500), $50^{\circ} 53^{\prime} 07^{\prime \prime} \mathrm{N}, 22^{\circ} 40^{\prime} 11^{\prime \prime} \mathrm{E}, 205 \mathrm{~m}$, leg. P. Chmielewski, R. Piwowarczyk, 11.07.2008 (KTC), (P i w o w a r c zyk et al. 2011, Piwowarczyk, 2012 b); FF: 98 - Brzuska, formerly arable land, leg. M. Wolanin, 11.07.2008 (KRA); GE: 91 - Żurawnica near Zwierzyniec - fallow fields and roadsides on hill-

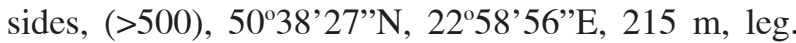
P. Chmielewski, R. Piwowarczyk, 25.06.2008 (KTC), (Piwowarczyk et al. 2011, Piwowarczyk, 2012 b); 92 - Bliżów, fallow fields and fragments of mesoxerothermic grasslands, (>50), 50 $36^{\circ} 23^{\prime \prime} \mathrm{N}$, 2307’37'E, 215 m, leg. W. Michalczuk, R. Piwowarczyk, 16.07.2006 (KTC), (Piwowarczyk et al. 2011, Piw ow arczyk, 2012b); GF: 15 - initial xerothermic grasslands on the slope of the Sołokija valley in the „Żurawce" ecological site (>300), 50²3'37'N, 2333'24'E, 228 m, leg. P. Chmielewski, R. Piwowarczyk, 09.06.2007 (KTC), (P i w o w a r c zyk et al. 2011, Piwowarczyk, 2012 b); 25 - Machnów Stary, fallow fields and initial xerothermic grasslands in the „Machnowska Gora” reserve (>500), 50'22'23”N, 23³4'51'E, $230 \mathrm{~m}$, leg. P. Chmielewski, R. Piwowarczyk, 09.06.2007 (KTC), (Piwowarczyk et al. 2011, Piwowarczyk, 2012 b); 80 - Winna Góra Mt near Przemyśl (K o tu la, 1881).

Remark: The herbarium material (KRAM) documenting the location in the vicinity of Jaksice near Miechów and Szczotkowice near Działoszyce (Kozłowska, 1923; Tacik, 1959) concerns Orobanche lutea and O. kochii. Mądalski (1973) re- ports $O$. loricata based on the specimen collected by J. Krupa in Karniowice, Chrzanów district, 14.07.18.... Figures were also made based on this specimen. The note in the study on the presumptive host Artemisia campestris indicates that this information was not provided with the herbarium specimen. I could not verify the determination because the herbarium documentation is missing in the available Polish herbaria. It is possible it could have been $O$. picridis.

\section{Ukraine}

Specimens documenting a few localities of Orobanche picridis within the present Ukraine borders (the former Tarnopol province in Poland in the interwar period) were found in Polish herbaria. They were collected mostly in the Lviv, Zolochiv and Buczacz districts (Fig. 2).

List of localities: 1 . on the margin of a forest planted with pine SW of Trościaniec Mały village (Trostyanets) near Złoczów (Zolochiv), leg. J. Mądalski, 08.08.1938 (KRAM, 494833); 2. in a glade with thickets over a rocky wall on the left edge of the Dniester ravine, SW of Dźwinogród village (Dzvenyhorod) near Mielnica (Mel'nytsya), leg. J. Mądalski, 18.08.1936 (KRAM, 494831) (specimen attached to Picris hieracioides); 3. near a small steppe patch by the Las Oszowica forest on the "Szepeta" hill, Kruhów near Sassów (Sasiv), leg. J. Mądalski, 08.07.1936 (KRAM, 494838, 494837); 4. on a sunny chalky slope NE of the Łysówka hill arm, Winniki (Vynnyky) near Lviv, leg. J. Mądalski, 25.07.1938 (KRAM, 494836, 12051).

\section{Preferred habitats and phytocoenoses in Poland}

In Poland Orobanche picridis prefers weakly established habitats, strongly sun-exposed, on heavy chalky rendzina, mostly S, SW and SE-facing. These are wastelands, mid-field fallows, field margins, abandoned fields, orchards (it often occurs in cherry orchards or on their margins at the localities in Wesołówka or Pęczelice) and pastures, xerothermic grasslands, located on flat or hilly terrains, hillsides and river valley slopes. These are usually transitional communities within semiruderal pioneer xerothermic communities of the class Artemisietea vulgaris (the optimum in Dauco-Picridetum hieracioidis) with an admixture of species belonging to Agropyretea intermedio-repentis or less frequently in xeric meadow communities (Arrhenatherion elatioris); with a high contribution of xerothermic species of the Festuco-Brometea and Trifolio-Geranietea sanguinei classes, as well as segetal species of the Stellarietea mediae class (Table 1). It is recorded less frequently in typical xerothermic grasslands, usually initial, low-cover or ecotone grassland/ wasteland systems, of the Cirsio-Brachypodion pinnati alliance (P i w o w a r c z y k, 2010, 2011, 2012 a,b; 
Piw ow arc zy k et al. 2011) (Table 1). In Poland it is recorded between an altitude of 140 and $435 \mathrm{~m}$.

Threats and conservation recommendations

Orobanche picridis is listed as an endangered species (EN) in the Red Book (Zarzycki, 2001; Piw ow a r c z k , 2012 b), as a rare and endangered species (R) on the Polish Red List (Z arz y cki and S z e lą g, 2006), endangered (EN) in Silesian voivodeship (Urbis z and Paruse 1, 2012) and endangered (EN) in the Wyżyna Małopolska upland (B r ó ż and Prze my ski, 2009). It is strictly protected. Secondary plant succession as well as unstable, pioneer and often synanthropic habitats it invades are the main threats to the species. Protection of $O$. picridis must aim to conserve its habitats. This is often difficult, as $O$. picridis frequently grows at privately-owned sites, in abandoned fields or in the ecotone between managed fields. Wastelands can be easily transformed or forested. Herbicides also pose an important threat. Its localities are rarely found in legally protected areas, and even in those active methods are not used to protect the species. As these sites are not extensively managed, the abundance of the herb layer increases, especially by expansive species, i.e. Arrhenatherum elatius and Solidago species, and thickets and the host, together with the broomrape, are displaced. Due to the small size of areas occupied by the species and necessary active protection, ecological sites where extensive management methods are used (controlling grassland cover increases due to mowing and periodical soil scarifying) should be established. Sowing the host and controlling the localities may be recommended. Periodic soil disturbance is especially useful in seed penetration near the host's roots. The abundance of $O$. picridis in Wesołówka gradually decreased in wastelands as the vegetation cover increased, whereas it occurred exceptionally numerously in sites rooted by boars. A similar effect were observed in Sławków-Kozioł (Ł. K r a j e w s k i, 2009, unpbl.).

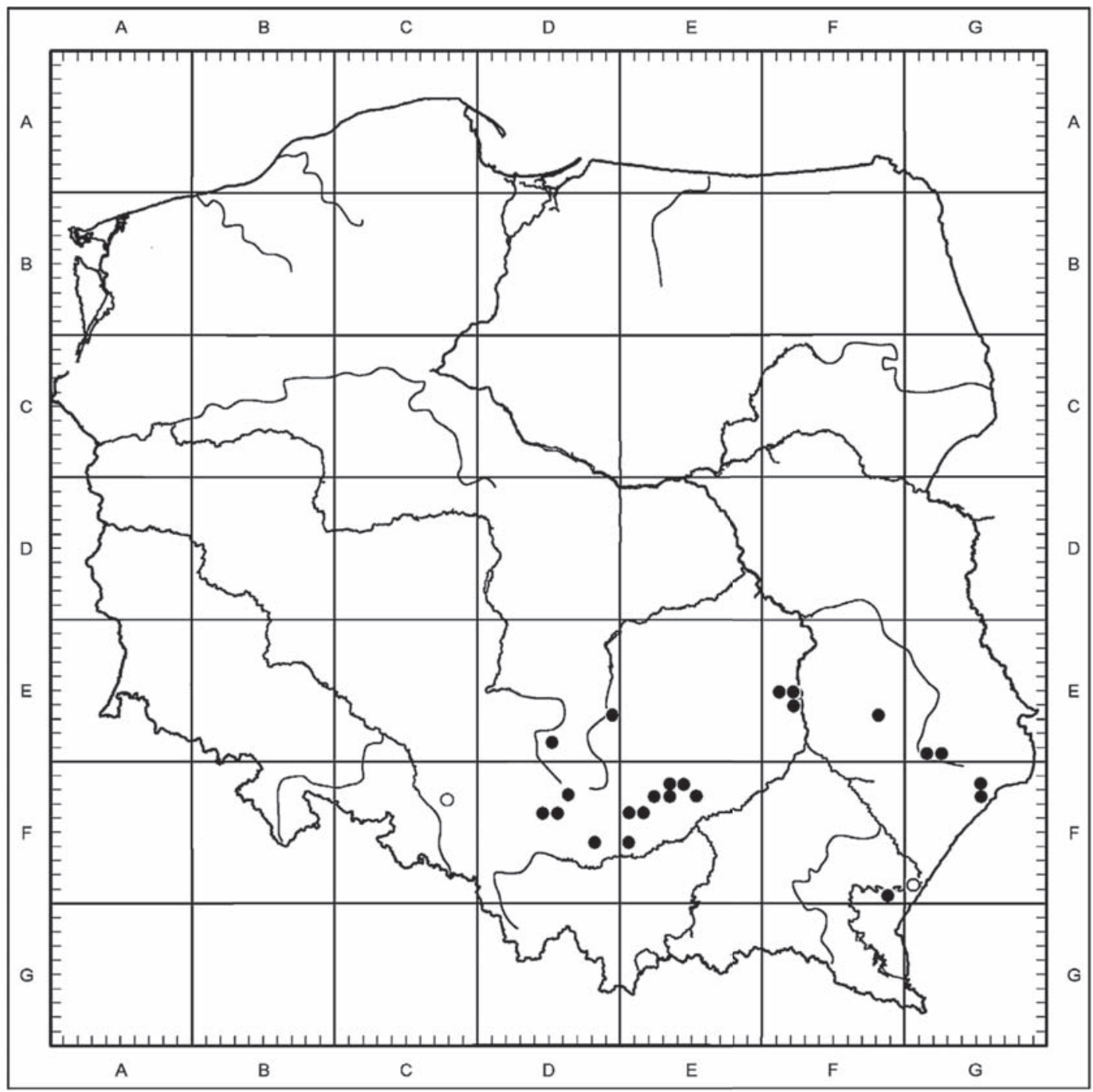

Fig. 1. The distribution of Orobanche picridis in Poland $(-$ new or confirmed locality, $\bigcirc$ - unconfirmed locality). 


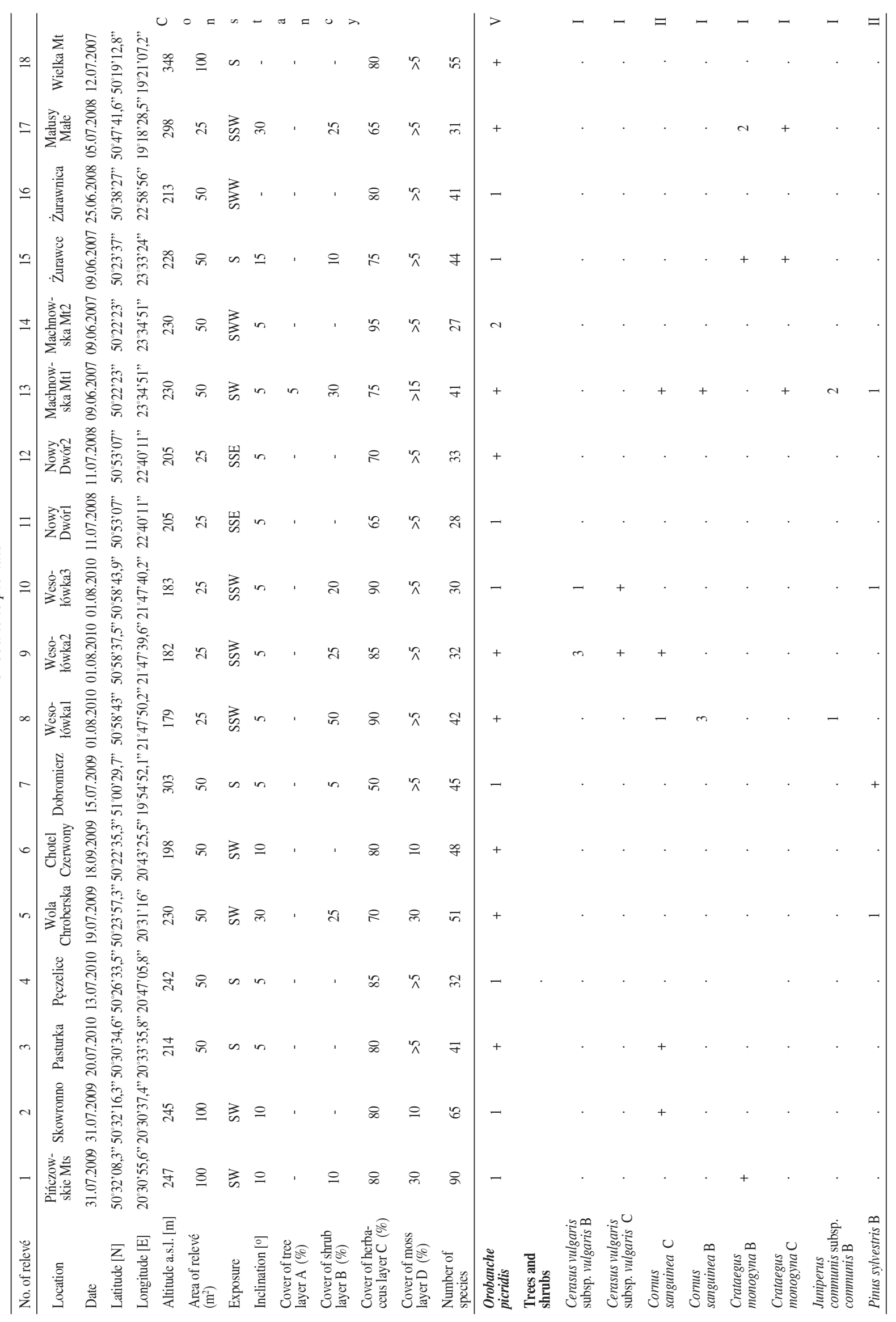




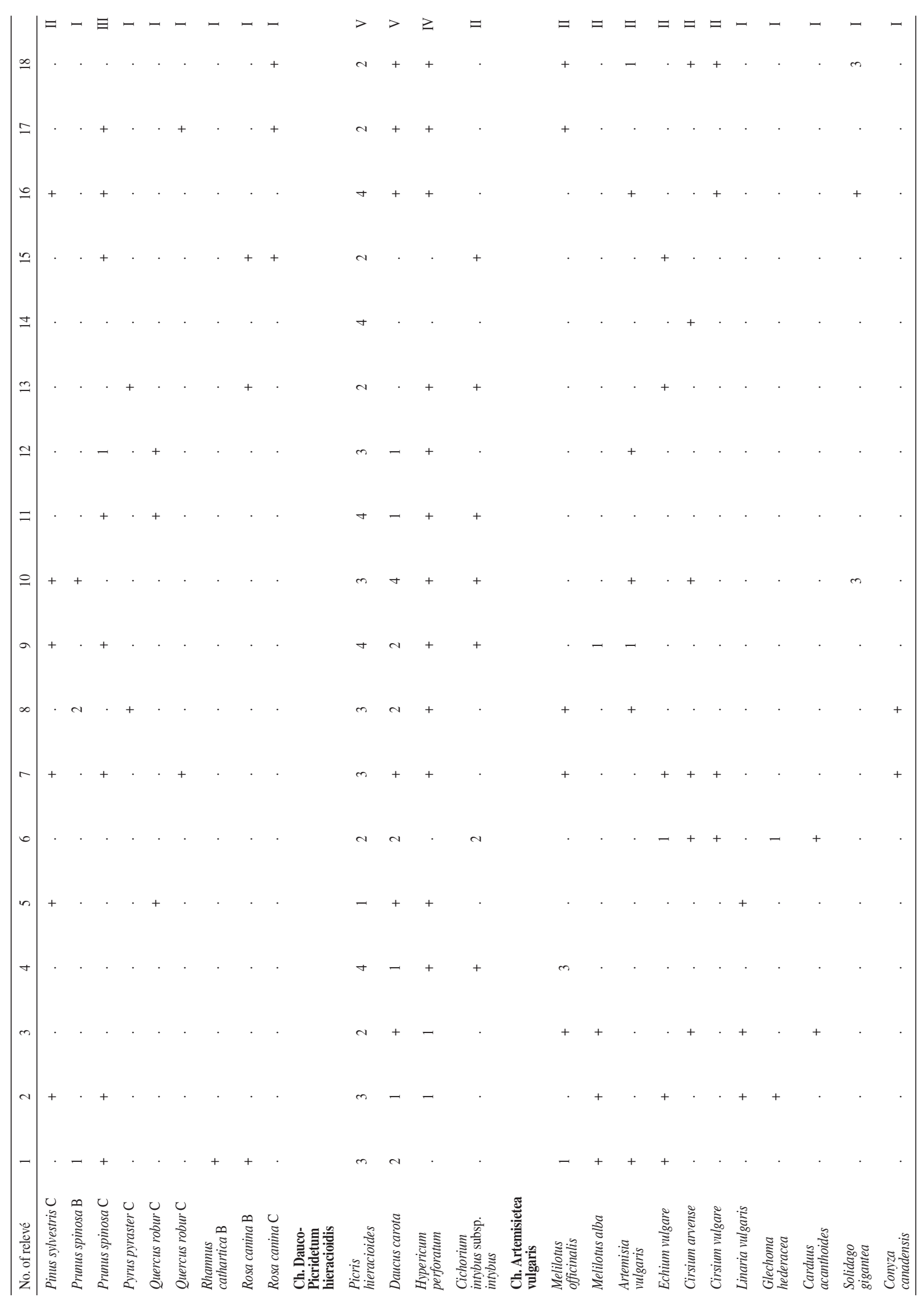




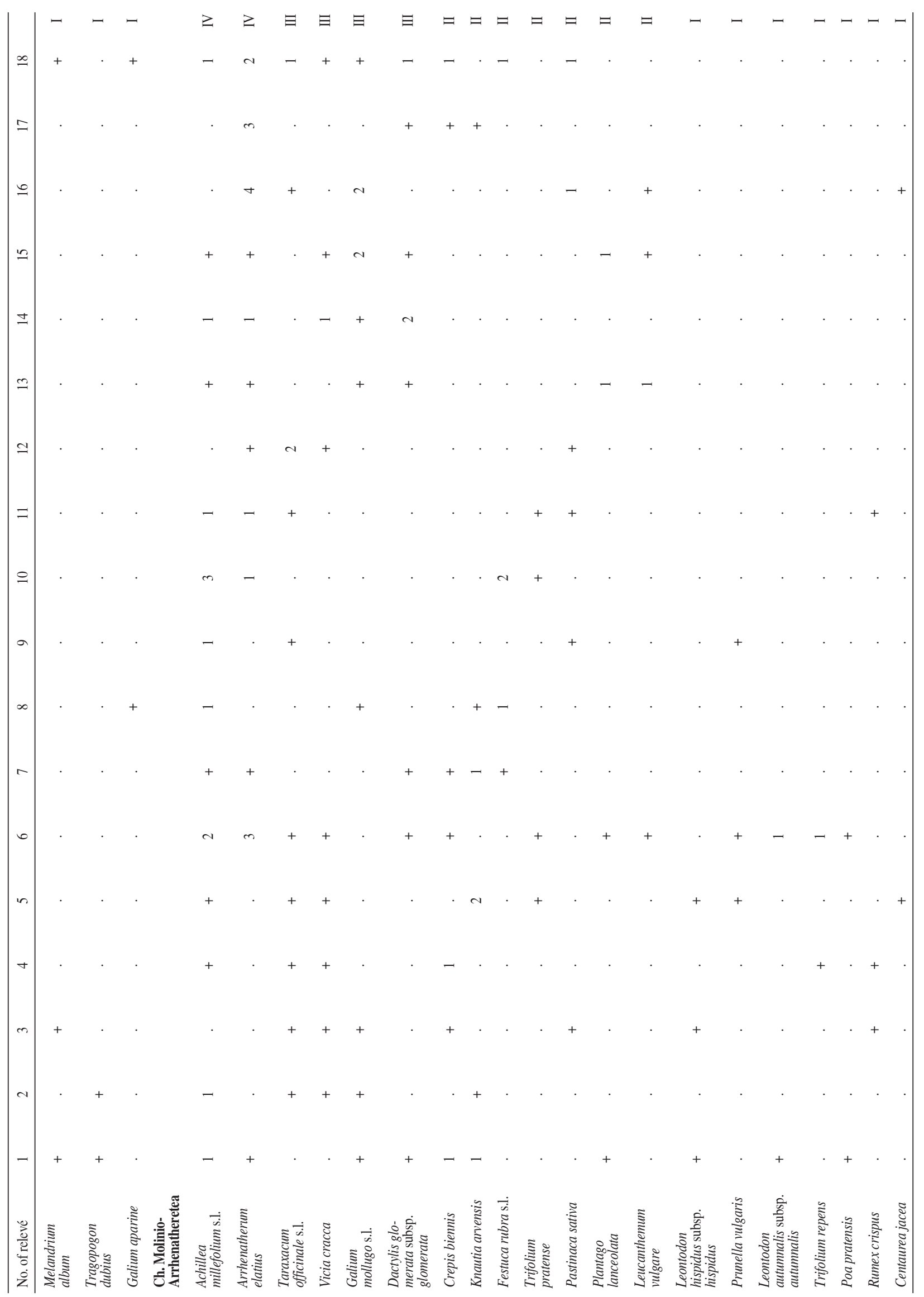




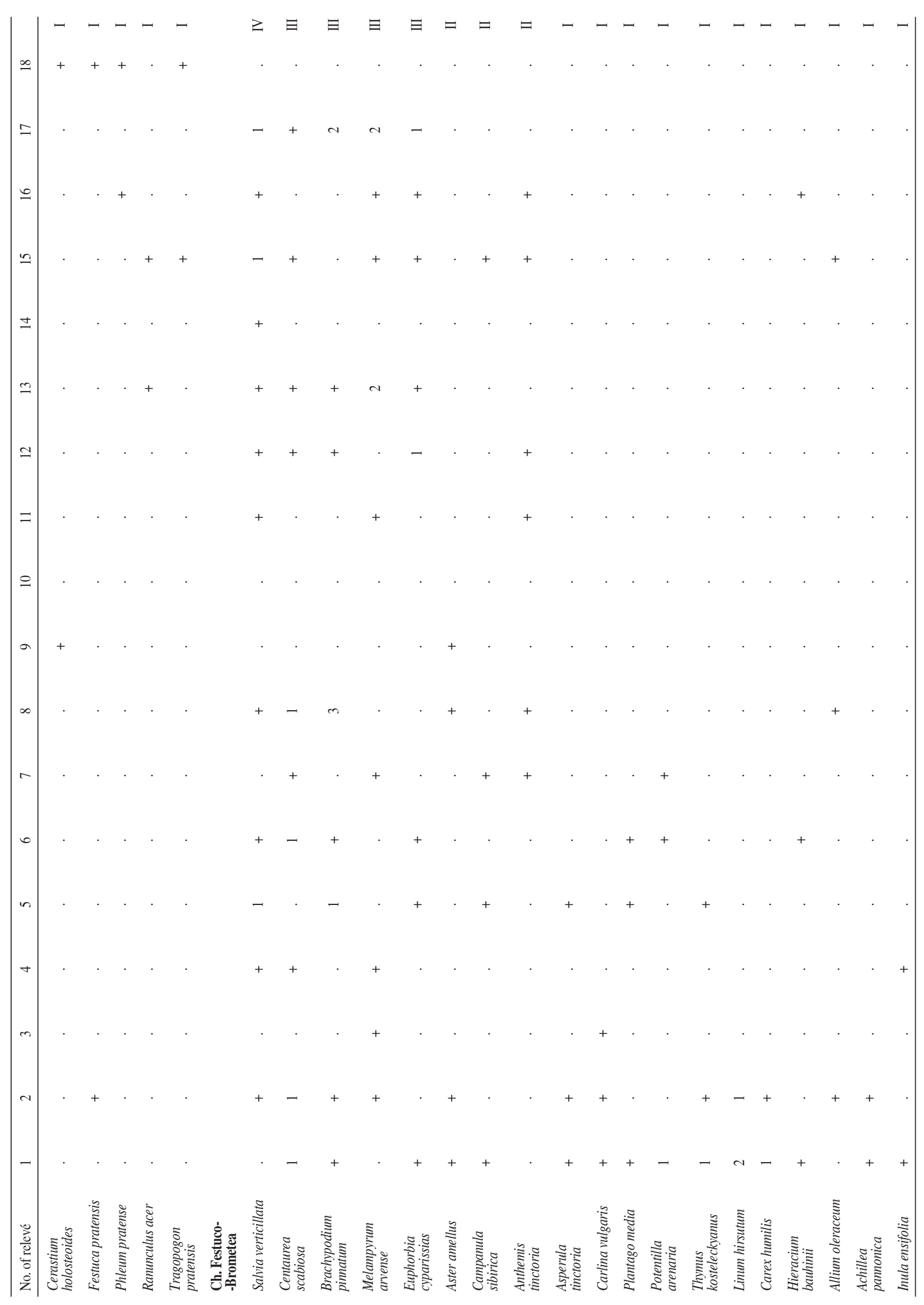




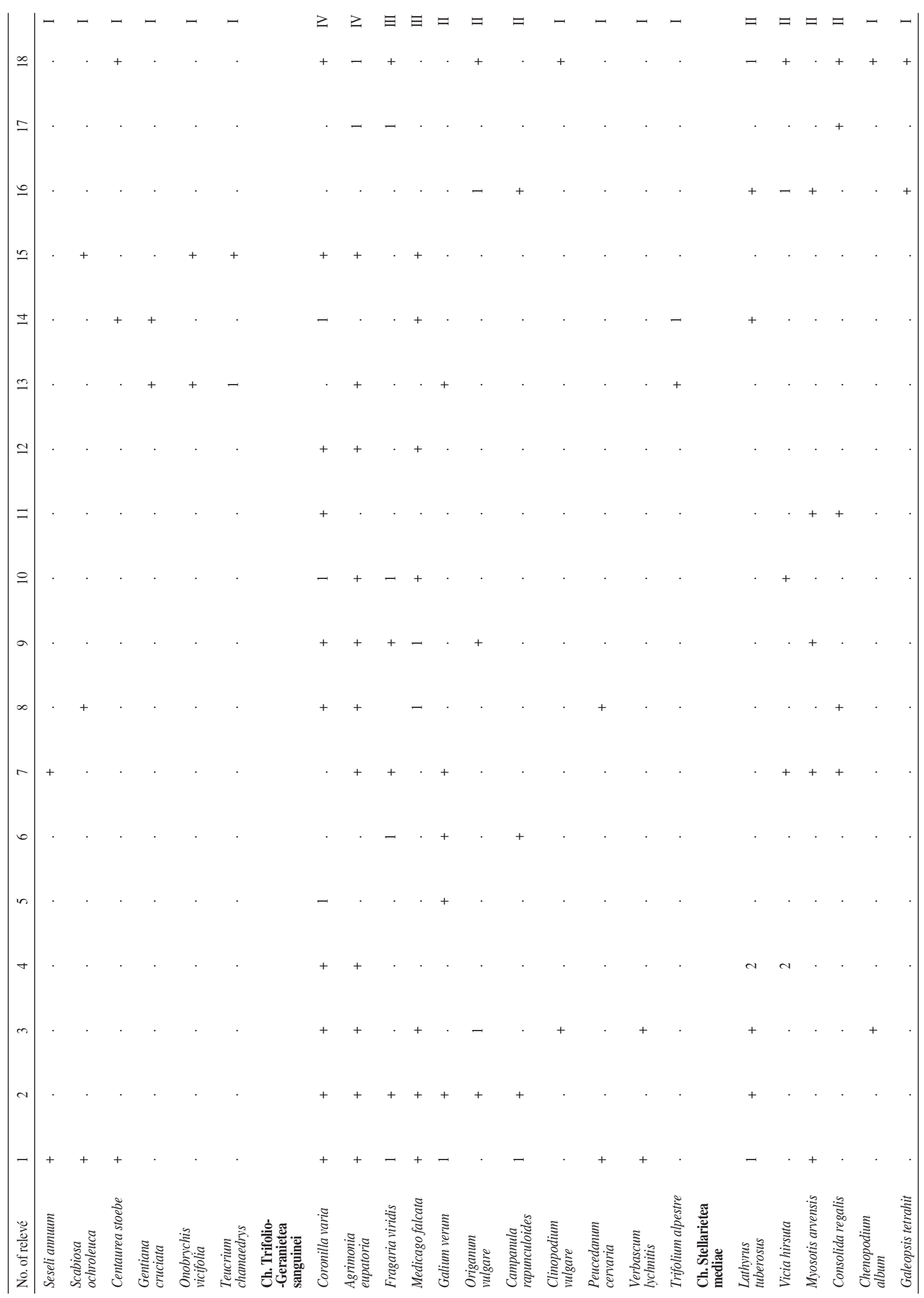




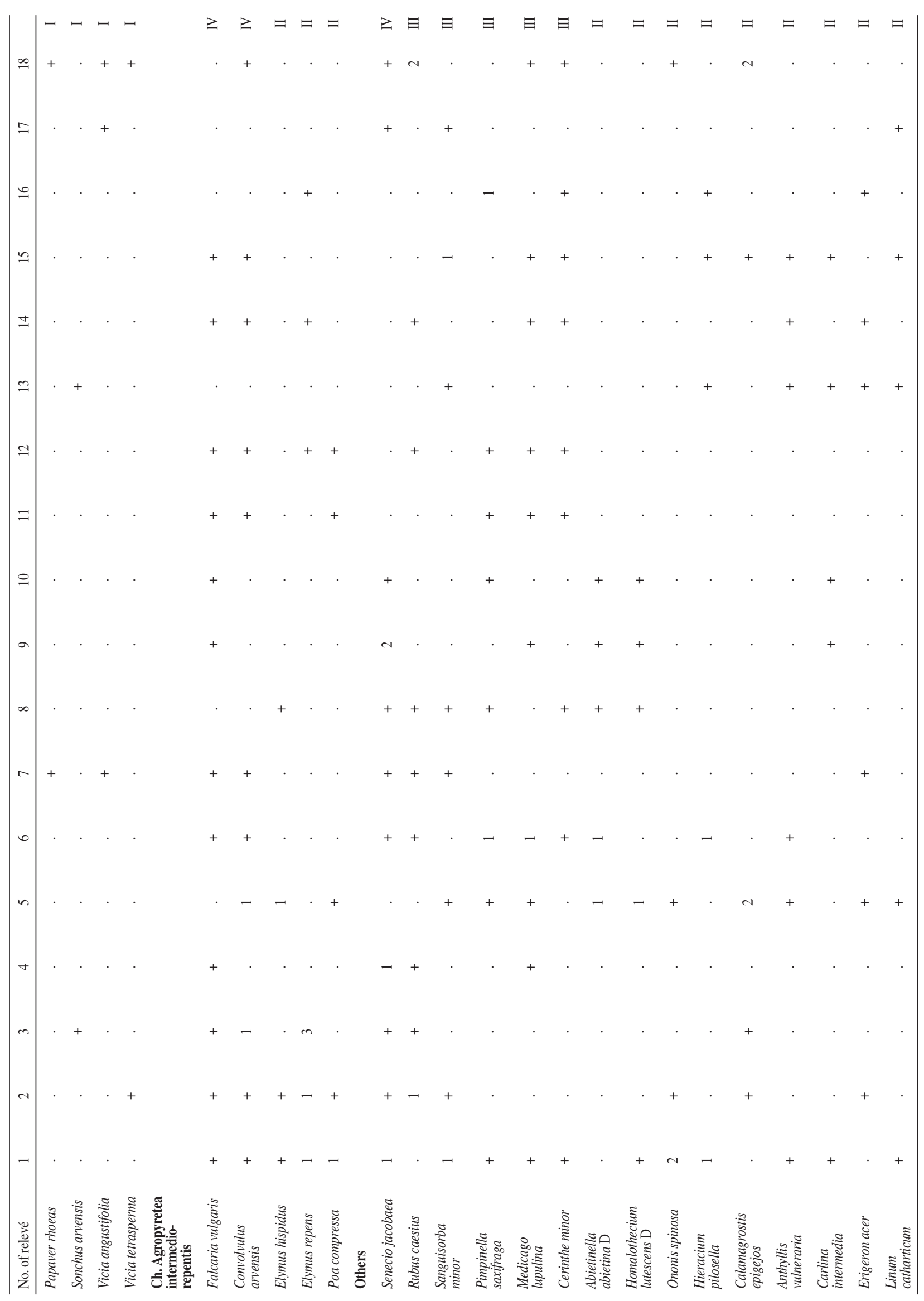




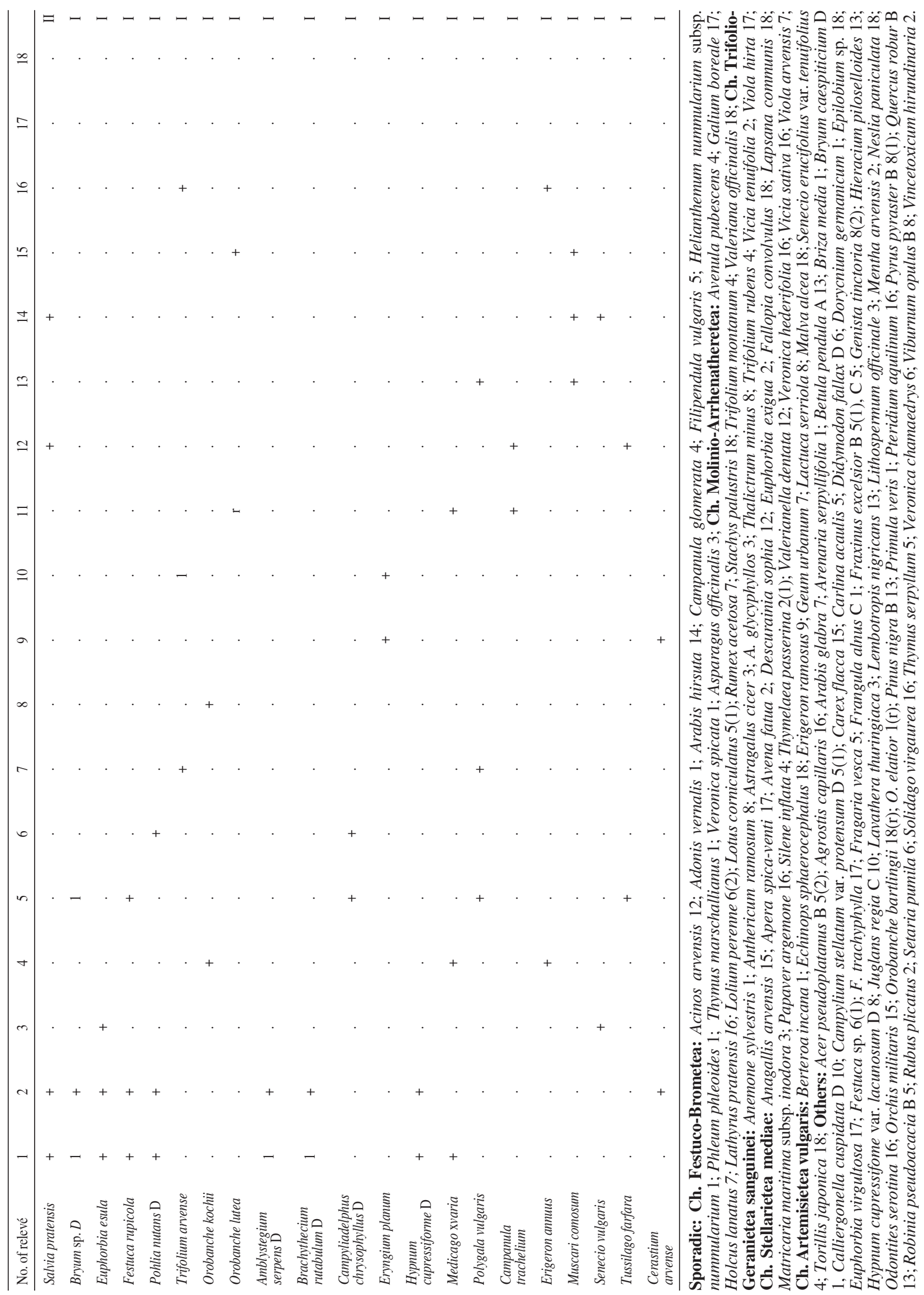




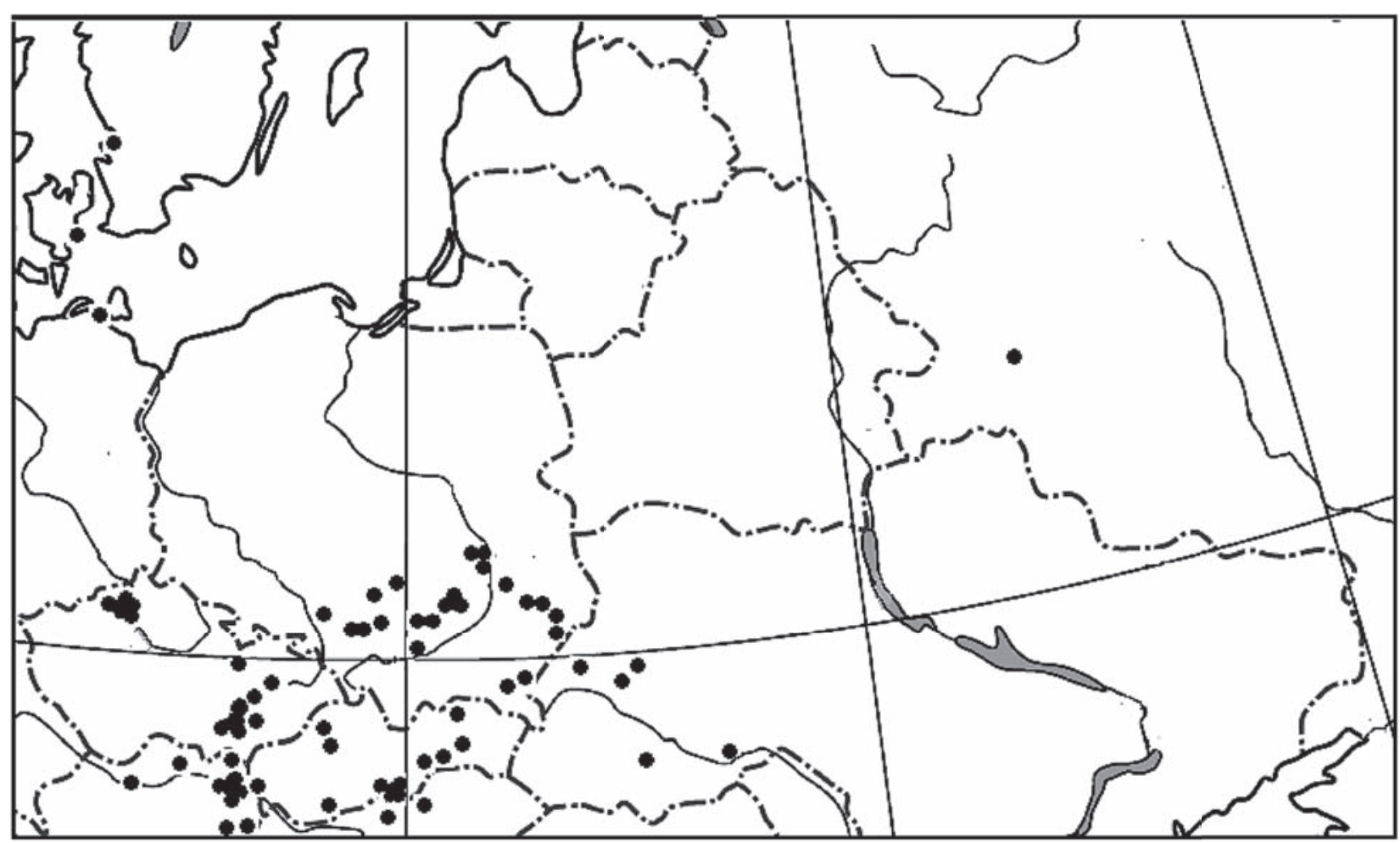

Fig. 2. The distribution of Orobanche picridis at the NE range limit, according to Pusch and Günther 2009 (modified and supplemented).

\section{DISCUSSION}

Orobanche picridis is strongly threatened in Central Europe. Many of its localities have not been confirmed, e.g. in Germany, the Czech Republic, Slovakia. The localities of $O$. picridis in Poland and Ukraine are the north-eastern limit of its range. In Poland it has been reported from 34 sites, nearly all of which have been recorded in the last ten years. In Poland it mostly occurs in the south and south-east, in the Wyżyna Śląsko-Krakowska, Wyżyna Małopolska and Wyżyna Lubelska uplands, Middle Roztocze, Small Polesie, and the Pogórze Przemyskie foreland. Four unknown localities were discovered in the collections in the KRAM herbarium, in the former Tarnopol province within Poland's interwar borders. They were recorded chiefly in Ukraine in the Lviv, Zolochiv, and Buczacz districts. These specimens were collected in the 1930s and their current status must be confirmed in field investigations. Soil test pits performed at over 20 sites of O. picridis in Poland have shown that it parasitizes only Picris hieracioides.

In Poland the optimum occurrence of Orobanche picridis is recorded in the community Dauco-Picridetum hieracioidis between an altitude of 140 and $435 \mathrm{~m}$, usually over $200 \mathrm{~m}$. The highest altitude reported from Central Europe, ca. 400 m, is in Hüntwangen in Switzerland (P u s ch and Günther, 2009).
Similar phytocoenotic conditions are observed for the species in Central Europe. The number of individuals at the sites varies considerably and changes every year. They may not occur each year. A sudden and abundant occurrence with high host cover and its disappearance after a few years or its re-occurrence a few years later are characteristic of the species. O. picridis is very sensitive to an increase in grassland cover and succession changes. Its populations at the localities range from a few shoots to a few thousand shoots. The most abundant populations consisting of a few hundred to over a thousand shoots were recorded at the sites in $\mathrm{Mu}$ rawy Dobromierskie, Wesołówka, Góry Pińczowskie Mts or near Dąbrowa Górnicza, and in SE Poland: Nowy Dwór, Machnowska Góra Mt, Żurawnica.

Species biodiversity at the localities occupied by Orobanche picridis is also high. Many species extremely rare in Poland were observed when phytosociological relevés were performed in the communities with $O$. picridis. These include: Adonis vernalis, Dorycnium germanicum, Linum hirsutum, Orobanche bartlingii, O. elatior, O. kochii, O. lutea, Senecio erucifolius var. tenuifolius, Thymelaea passerina, Carlina onopordifolia, Linosyris vulgaris, Orthanta lutea, Lathyrus latifolius and other.

Processes of secondary succession must be controlled and the initial type and weak cover of the localities occupied by Orobanche picridis must be preserved 
to protect the species. It is also recommended to control the localities and to monitor the abundance of the parasite and its host.

\section{Acknowledgements}

The author thanks Prof. Adam Zając for his helpful comments on the manuscript. The author is also grateful to Adam Stebel for determining moss species. This work was supported by the Polish State Committee for Scientific Research (KBN grant no. NN303357733 (2008-2009) and NN303551939 (2010-2012).

\section{REFERENCES}

Bróż E., Nobis M., Piwowarczyk R., 2001. Nowe stanowiska Orobanche picridis w Polsce. Chroń. Przyr. Ojcz. 57(5): 101-104. (in Polish)

Bróż E., Przemyski A., 2009. The red list of vascular plants in the Wyżyna Małopolska upland (S Poland). pp. 123-136. [In:] Rare, relict and endangered plants and fungi in Poland. Z. Mirek, A. Nikel (eds), W. Szafer Intitute of Botany, Polish Academy of Sciences, Kraków.

Delipavlov D., 1995. Orobanchaceae Vent. [In:] Fl. Republ. Bulgaricae. S. Kožuharov (ed.), 10: 291-325. Editio Acad. Prof. Marin Drinov, Serdicae.

Dom in a G., A rrigoni P.V., 2007. The genus Orobanche (Orobanchaceae) in Sardinia. Fl. Medit. 17: 115-136.

Feráková V., Maglocky Š., Marhold K., 2001. Červený zoznam papradorastov a semenných rastlín Slovenska. [In:] Červený zoznam rastlín a živočíchov Slovenska, D. Baláž, K. Marhold, P. P. Urban (eds). Ochr. Prír. 20, Suppl. 44-76, Banská Bystrica. (in Slovak)

He s ele r U., 2006. Wiederfund der Bitterkraut-Sommerwurz Orobanche picridis F. W. Schultz im Saarland. Abh. Delattinia, 32: 147-155. (in German)

Korneck D., Schnittler M., Vollmer I., 1996. Rote liste der Farn- und und Blütenpflanzen (Pteridophyta \& Spermatophyta) Deutschlands. Schrift. Vegetationsk. 28: 21-187. (in German)

Kotov M.I., 1999. Orobanchaceae. [In:] Opredelitiel vysshikh rastenii Ukrainy. Y.N. Prokudin (ed.). Fitosociocentr, Kiev. (in Ukrainian)

Kot u la B ., 1881. Spis roślin naczyniowych z okolic Przemyśla. Spraw. Komis. Fizyjogr. AU 15: 1-90. (in Polish)

Kozłowska A., 1923. Stosunki geobotaniczne ziemi Miechowskiej. Spraw. Komis. Fizjogr. PAU, 57: 1-68. (in Polish)

Kreutz C.A.J., 1995. Orobanche. The European broomrape species. Central and northern Europe. Limburg.

Kucharczyk M., 2001. Distribution Atlas of Vascular Plants in the Middle Vistula River Valley. UMCS Press. Lublin.

Matuszkiewicz W., 2006. Przewodnik do oznaczania zbiorowisk roślinnych Polski. Vademecum Geobota- nicum. Wydawnictwo Naukowe PWN Warszawa. (in Polish)

Mądalski J., 1967. Orobanchaceae. [In:] Flora Polska. B. Pawłowski (ed.). Tom XI: 25-53; Warszawa, Kraków. (in Polish)

Mądalski J., 1973. Atlas flory polskiej i ziem ościennych (Florae Polonica terrarumque adiacentium iconographia). Scrophulariaceae (Pars 4), Orobanchaceae. Tom XVII (1). Państwowe Wydawnictwo Naukowe, Warszawa-Wrocław-Kraków. (in Polish)

Mirek Z., Musiał L., Wójcicki J.J., 1997. Polish herbaria. Polish Bot. Stud. Guideb. Ser. 18: 1-110.

Mirek Z., Piękoś-Mirek H., Zając A., Zając M., 2002. Flowering plants and pteridophytes of Poland - a checklist. [In:] Biodiversity of Poland. Z. Mirek (ed.), Instytut Botaniki im. W. Szafera, Polska Akademia Nauk, Kraków, 1: 1-442.

Nobis M., Nobis A., 2010. Nowe dane dotyczące występowania storczyka purpurowego Orchis purpurea Huds. (Orchidaceae) na Wyżynie Małopolskiej. / New data concerning the occurrence of lady orchid Orchis purpurea Huds. (Orchidaceae) in the Wyżyna Małopolska Upland. Chrońmy Przyr. Ojcz. 66(2): 149155. (in Polish with English summary)

Piwowarczyk R., 2006. Róża francuska Rosa gallica L. na Przedgórzu Iłżeckim (Wyżyna Małopolska). / Rosa gallica L. in the Iłża Foreland (Małopolska Upland). Chroń. Przyr. Ojcz. 62: 55-60. (in Polish with English summary)

Piwowarczyk R., 2010. Rośliny naczyniowe wschodniej części Przedgórza Iłżeckiego (Wyżyna Małopolska). I Vascular plants of the eastern part of the Iłża Foreland (Małopolska Upland). Prace Bot. 43: 1-344. (in Polish with English summary)

Piwowarczyk R., 2012a. The genus Orobanche L. (Orobanchaceae) in the Małopolska Upland (S Poland): distribution, habitat, host preferences and taxonomic problems. Biodiv. Res. Conserv. 26 (in print).

P iw ow a rczyk R., 2012b. Orobanche picridis F. W. Schultz - Zaraza goryczelowa. [In:] Polska czerwona księga roślin. R. Kaźmierczakowa, K. Zarzycki (eds), Polish Academy of Sciences, W. Szafer Institute of Botany $\&$ Institute of Nature Conservations. (in print)

Piwowarczyk R., 2012c. The productivity of seeds of Orobanche picridis F. W. Schultz (Orobanchaceae) - a study of intraspecific and environmental interactions. Pol. J. Ecol. (in review)

Piwowarczyk R., Przemyski A., 2009. New locality of Orobanche coerulescens Stephan ex Willd. (Orobanchaceae) at the NW limit of its geographical range. Acta Soc. Bot. Pol. 78(4): 291-295.

Piwowarczyk R., Przemyski A., 2010. Distribution and habitat preferences declining species of Orobanche arenaria (Orobanchaceae) at the northern limit of its geographical range. Acta Soc. Bot. Pol. 79(1): 43-50.

Piwowarczyk R., Chmielewski P., Cwener A., 2011. The distribution and habitat requirements of the 
genus Orobanche L. (Orobanchaceae) in SE Poland. Acta Soc. Bot. Pol. 80(1): 37-48.

Procházka F., (ed.) 2001. Červený a černý seznam cévnatých rostlin České republiky (stav v roce 2000), Příroda, Praha. (in Czech)

Pusch J., Günther K.F., 2009. Orobanchaceae (Sommerwurzgewächse). [In:] Illustrierte Flora von Mitteleuropa, G. Hegi (ed.). Bd. 6/1A, Lieferung 1; 1-99. Weissdorn-Verlag Jena. (in German)

Rothmaler W., Jäger E.J., Werner K., 2002. Exkursionsflora von Deutschland - Kritischer Band 4. Berlin. (in German)

Rumsey F. J., 2007. A reconsideration of Orobanche maritima Pugsley (Orobanchaceae) and related taxa in southern England and the Chanell Islands. Watsonia, 26: 473-476.

Stoyanov K.H., 2009. Chorology and critical notes on Orobanche subsect. Minores in Bulgaria. Phytologia Balcanica, 15(3): 351-360.

Szafer W., Kulczyński S., Pawłowski B., 1924. Rośliny polskie. Książnica - Atlas, Warszawa-Lwów. (in Polish)

Szeląg Z., 1996. Nowe stanowisko Orobanche picridis (Orobanchaceae) z okolic Krakowa. / New locality of Orobanche picridis (Orobanchaceae) near Kraków. Fragm. Flor. Geobot. Ser. Polonica 3: 399-402. (in Polish)

Tacik T., 1959. Zapiski florystyczne z południowej części Wyżyny Małopolskiej wraz z uwagami o zasięgach i wędrówkach kilku rzadszych gatunków. Fragm. Flor. Geobot. 5 (3): 365-383. (in Polish)

Teryokhin E.S., Schibakina G.B., Serafimovitsch N.B., Kravtzova T.I., 1993. Opredelitel Sarasychovych Flory SSSR. Nauka, Sankt Petersburg. (in Russian)

Tzvelev N. N., 2006. Orobanchaceae Vent. [In:] Flora sredney polosy evropeiskoy chasti Rossii, P. F. Mayevsky, KMK, Moskwa. (in Russian)

Urbisz A., Parusel J.B., (ed.) 2012. Czerwona lista roślin naczyniowych województwa śląskiego. [In:] Raport o stanie przyrody województwa śląskiego. Centrum Dziedzictwa Przyrody Górnego Śląska, Katowice. (in print) (in Polish)

Zają c A., 1978. Założenia metodyczne "Atlasu rozmieszczenia roślin naczyniowych w Polsce". Wiad. Bot. 22(3): 145-155. (in Polish)

Zając A., Zając M., (eds) 2001. Atlas rozmieszczenia roślin naczyniowych w Polsce. / Distribution Atlas of Vascular Plants in Poland. Nakładem Pracowni Chorologii Komputerowej Instytutu Botaniki Uniwersytetu Jagiellońskiego, Kraków. (in Polish)

Zając M., Zając A., Zemanek B.,(eds). 2006. Flora Cracoviensis Secunda (Atlas). Edited by Laboratory of Computer Chorology, Institute of Botany, Jagiellonian University, Cracow.

Zarzycki K., 2001. Orobanche picridis F. W. Schultz Zaraza goryczelowa. [In:] Polska czerwona księga roślin: 342-343, R. Kaźmierczakowa, K. Zarzycki (eds). Polish Academy of Sciences, W. Szafer Institute of Botany \& Institute of Nature Conservations. (in Polish)

Zarzycki K., Szeląg Z., 2006. Red list of the vascular plants in Poland. [In:] Red list of plants and fungi in Poland. Z. Mirek, K. Zarzycki, W. Wojewoda, Z. Szeląg (eds). W. Szafer Institute of Botany, Polish Academy of Sciences, Kraków.

\section{Rewizja rozmieszczenia i analiza ekologiczna Orobanche picridis (Orobanchaceae) na NE granicy zasięgu, w Polsce i na Ukrainie}

\section{Streszczenie}

Orobanche picridis należy do gatunków submediterrańsko-subatlantyckich. Zwartym zasięgiem obejmuje głównie Europę południowo-zachodnią. Stanowiska w Polsce i na Ukrainie tworzą północno-wschodni kres zasięgu gatunku. Należy do holopasożytów korzeniowych i pasożytuje głównie na Picris hieracioides. W Polsce jest gatunkiem silnie zagrożonym, zamieszczonym w czerwonej księdze i liście, podlega także ścisłej ochronie prawnej. O. picridis notowany jest w kraju z 34 stanowisk, z czego niemal wszystkie znalezione zostały w ostatnim 10-leciu. W Polsce występuje głównie na południu kraju, na Wyżynie Śląsko-Krakowskiej, Wyżynie Małopolskiej, Wyżynie Lubelskiej, Roztoczu Środkowym, Małym Polesiu oraz na Pogórzu Przemyskim, natomiast na Ukrainie, w dawnym województwie tarnopolskim. Populacje gatunku na stanowiskach wynoszą od kilku do ponad tysiąca pędów. Preferuje inicjalne siedliska, silnie nasłonecznione, często na ciężkiej rędzinie kredowej, tj. odłogi, ugory śródpolne, obrzeża pól, porzucone pola, sady i pastwiska, murawy kserotermiczne. Są to głównie zbiorowiska przejściowe w obrębie półruderalnych kserotermicznych zbiorowisk pionierskich z klasy Artemisietea vulgaris (optimum w Dauco-Picridetum hieracioidis) z domieszką gatunków z Agropyretea-intermedio-repentis lub rzadziej w zbiorowiskach suchych łąk (Arrhenatherion elatioris); z dużym udziałem gatunków kserotermicznych z klasy Festuco-Brometea i Trifolio-Geranietea sanguinei, a także segetalnych z klasy Stellarietea mediae. W typowych murawach kserotermicznych notowany rzadziej, zazwyczaj w inicjalnych lub słabo zwartych ich postaciach ze związku Cirsio-Brachypodion pinnati. Głównym zagrożeniem dla gatunku jest wtórna sukcesja roślinności, a także niestabilny, często synantropijny charakter siedlisk. Ochrona siedlisk gatunku nie jest łatwa, gdyż zaraza rośnie często na gruntach prywatnych, w miejscach porzuconych pól, 
lub w ich strefie kontaktowej, skąd zagrożeniem jest wpływ herbicydów. Odłogi często są przekształcane w pola lub zostają zalesione. W celu ochrony należy, przede wszystkim, przeciwdziałać wzrostowi zwarcia siedlisk na skutek koszenia i okresowego płytkiego przedrapywania gleby, kontrolować liczebność żywiciela oraz objąć stanowiska monitoringiem przyrodniczym. 